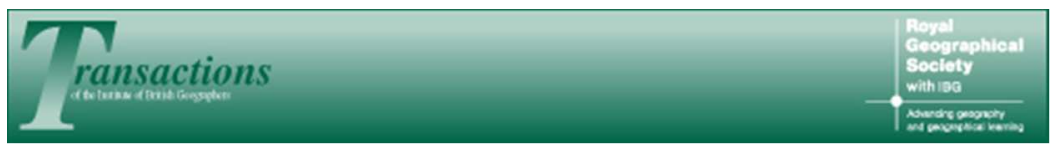

\title{
New Spaces for Nature: \\ the re-territorialization of biodiversity conservation under neoliberalism in the UK
}

\begin{tabular}{|c|l|}
\hline Journal: & Transactions of the Institute of British Geographers \\
\hline Manuscript ID: & TIBG-RP-Aug-2012-0072.R2 \\
\hline Manuscript Type: & Regular Paper \\
\hline Keywords: & $\begin{array}{l}\text { conservation, neoliberalization, territorialization, biodiversity, landscape } \\
\text { ecology, ecological restoration }\end{array}$ \\
\hline & $\begin{array}{l}\text { Biodiversity conservation is a fundamentally spatial practice. For more than } \\
\text { a century, conservation's leading strategy has been the establishment of } \\
\text { protected areas. Governance by the state has been central to } \\
\text { conservation's claim to territory. In the UK, the established approach to } \\
\text { biodiversity conservation concentrated on spatial strategies of } \\
\text { territorialization to secure particular outcomes in relatively small pieces of } \\
\text { land, set aside as protected areas. However, this strategy has begun to } \\
\text { change, and conservation's expanding territorial claims have been } \\
\text { expressed through new models of large-scale conservation. A series of } \\
\text { projects developed by non governmental conservation organisations seek } \\
\text { to extend conservation management over larger areas of land. In this } \\
\text { paper we consider these developments as a form of re-territorialisation, a } \\
\text { reframing and extension of conservation's spatial claims. We describe how } \\
\text { conservation's ambitions have been reformed and extended and discuss } \\
\text { evidence on the growth of large-scale biodiversity conservation projects in } \\
\text { the UK. We then consider the implications of these changes in the light of } \\
\text { the neoliberalization of conservation. }\end{array}$ \\
\hline
\end{tabular}




\title{
New Spaces for Nature: \\ the re-territorialization of biodiversity conservation under \\ neoliberalism in the $\mathrm{UK}$
}

\begin{abstract}
Biodiversity conservation is a fundamentally spatial practice. For more than a century, conservation's leading strategy has been the establishment of protected areas. Governance by the state has been central to conservation's claim to territory. In the UK, the established approach to biodiversity conservation concentrated on spatial strategies of territorialization to secure particular outcomes in relatively small pieces of land, set aside as protected areas. However, this strategy has begun to change, and conservation's expanding territorial claims have been expressed through new models of large-scale conservation. A series of projects developed by non governmental conservation organisations seek to extend conservation management over larger areas of land. In this paper we consider these developments as a form of reterritorialisation, a reframing and extension of conservation's spatial claims. We describe how conservation's ambitions have been reformed and extended and discuss evidence on the growth of large-scale biodiversity conservation projects in the UK. We then consider the implications of these changes in the light of the neoliberalization of conservation.
\end{abstract}

\section{Keywords}

Conservation, biodiversity, territorialization, neoliberalization, landscape ecology, ecological restoration. 


\section{Introduction}

In June 2011, the UK government published a White Paper on the natural environment, The Natural Choice: securing the value of nature (DEFRA 2011a). This was described as 'a bold and ambitious statement outlining the Government's vision for the natural environment over the next 50 years, backed up with practical action to deliver that ambition' (DEFRA 2011a).

The White Paper's purpose was to restate a public policy vision for conservation in England. Its language was economistic and ambitious. In line with the neoliberal turn in the management of nature (Peck and Tickell 2002; McCarthy and Prudham 2004; Robertson 2006, Castree 2008) and in the conservation of nature (Brockington and Duffy 2010, Hodge and Adams 2012, Büscher et al. 2012), it spoke of growth, prosperity, security and benefits. Conservation was presented not in terms of a narrow concern with preservation, but as a means of meeting wider social and economic purposes, not only 'reconnecting nature', but 'connecting people and nature for better quality of life', and 'capturing and improving the value of nature'. DEFRA observed that a 'healthy, properly functioning natural environment' was 'the foundation of sustained economic growth, prospering communities and personal wellbeing' (DEFRA 2011b). This economistic language about nature built directly on the idea of nature as providing 'services' to human society, which underpinned the the UK's National Ecosystem Assessment (NEA), published the previous month (UK NEA 2011).

This neoliberal market-based framing of biodiversity was tied closely to a new expansive intent in UK conservation. The White Paper adopted the positive language of success and expansion, rather than the more familiar conservation tropes of threat and retreat, offering a British version of 'wild hope' (Futerra 2010, Balmford 2012). In this it drew heavily on the recommendations of a committee reviewing provision for wildlife conservation in England, set up under the Labour administration but published three months after the election of the Conservative/Liberal Democrat coalition government in July 2010. Their report, Making Space for Nature, found that areas rich in wildlife in England were small and widely separated ('highly fragmented'), and unsuited to coping with pressures such as climate and population change and economic growth. Existing nature reserves and designated wildlife sites in 
England did not form a 'coherent and resilient' ecological network (Lawton et al. $2010, \mathrm{v})$. The committee recommended the establishment of an ecological network of 'more, bigger, better and joined' areas of wildlife habitat to prevent extinctions (Lawton et al. 2010, 3). Making Space for Nature provided the scientific case for the White Paper's language of physical extension and connectivity of conservation sites.

The England Biodiversity Group (comprising conservation, landowning, farming organisations and statutory bodies) captured this new spirit in a report published alongside the White Paper entitled Think Big: how and why landscape-scale conservation benefits wildlife, people and the wider economy (England Biodiversity Group 2011). This sought to tie conservation's new spatial ambition to claims about its benefits to society, arguing that 'landscape-scale conservation' (the pursuit of multiple benefits across a defined area) showed that 'enhancing nature can provide benefits to the local economy and quality of life' (England Biodiversity Group 2011, 7).

Conservation's growing territorial ambition in the UK is matched by developments elsewhere. In 2011, an editorial in Nature challenged conservation planners in the USA to also 'think big' (Anon 2011). The 1990s saw the development of massive trans-frontier conservation areas, for example in the work of the Peace Parks Foundation in South Africa (Duffy 2006, Büscher 2010). The idea of transfrontier conservation had 'taken South Africa by storm', expanding across political and economic boundaries (Dressler and Büscher 2008, 452). Globally, the number and extent of protected areas had expanded steadily since the United Nations adopted a 'World List of National Parks and Equivalent Reserves' in 1962 (Holdgate 1999). By the end of the twentieth century, there were protected area systems in every country, covering more than 2 million $\mathrm{km}^{2}, 12$ per cent of the Earth's land (Chape et al., 2005). In 2011, international targets for protected areas were expanded significantly at the Conference of the Parties to the Convention on Biological Diversity in 2010: Target 11 in the new Strategic Plan for Biodiversity 2011-2020 was to conserve at least 17 per cent of terrestrial and inland waters, and 10 per cent of coastal and marine areas by 2020 (CBD 2010). 
In this paper, we analyse factors associated with the development of large-scale conservation in the UK, and we present new evidence on the expanding territorial ambitions, drawing on a survey of the large conservation areas proposed by nongovernmental conservation organisations. We then situate these developments in the context of the neoliberalization of conservation and the changing role of the state as a conservation actor. First, we consider the importance of territorialization in the conservation strategies of state and non-state actors.

\section{Conservation territorialization}

Conservation is a fundamentally spatial practice (e.g. Tunbridge 1978). The establishment of protected areas has been a central strategy of conservation since the end of the nineteenth century (Sheail 2010), and a variety of forms of protected area are recognised (Ravenel and Redford 2005). From their commencement, the state has been the chief protagonist in conservation's spatial practices. The earliest national parks, in the American west, were created by the Federal Government, a model of state leadership and control emulated by colonial and independent governments across the world (Runte 1987, Adams 2004, Sheail 2010). Neumann (2004) locates the development of protected areas, both in the USA and British colonial Africa, firmly in the context of the state's proprietary claims. He argues that it comprises an integral element of the modern state's rationalizing and organizing enterprise (Scott 1998), 'as much an expression of modernism as skyscrapers' (Neumann 2004, 212).

The work of conservation involves the conceptual and practical placing of nature within specific spatial bounds, making both places and spaces (Hughes 2005). Thus Zimmerer $(2000,356)$ notes 'the expansive new geographies' involved in what he calls the 'conservation boom' of the 1990s, and describes how conservation territories take shape, 'through a spatiality inscribed as a result of various forces, such as science, governance and economics' $(2006,9)$. In the 1990s, satellite-based imaging systems, GIS software running on laptop computers and handheld GPS devices allowed scientists to make new assessments of land cover change globally in a practice of 'conservation biogeography' (Ladle and Whittaker 2011). Using such technologies of observation and analysis, international NGOs engaged in intensive and competitive science-based conservation planning (Margules and Pressey 2000), 
most notably Conservation International's identification of biodiversity 'hotspots', Myers et al., 2000).

The aim of such priority setting was to expand coverage of protected areas. Its method, making biomes and communities legible through mapping, produced 'topologies for environmental intervention', and zones of exclusion and inclusion (Brosius and Russell 2003, 49): as Bear (2012) notes in his study of scallop dredging in Wales, territorialization is implicitly exclusionary. In the case of conservation, protected areas are in most cases explicitly exclusionary, conceived and managed as places without people. The process of 'mapping, bounding, containing and charting and controlling nature and citizenry' (Neumann 2004, 202) tends to silence or sideline alternative (especially local) views (Bryant 2002; Fairhead and Leach 2003). The complex zoning systems of protected areas create new categories of illegal acts, such that poaching or the encroachment of settlements become construed as 'a defence of national sovereignty as well as a defence of the environment' (Schroeder 1999, 366). The creation of protected areas tends to lead towards coercive strategies (Peluso 1993), displacing local people, creating conservation refugees (Cernea and SchmidtSoltau 2006, Dowie 2009).

The process of territorialization is never completed, but is 'an iterative process which states must continually perform' (Wainwright and Roberts 2003, 201). Elden, following Foucault's lectures at the Collège de France 1977-8, notes that territory should be understood as an object of governance, 'a rendering of the emergent concept of 'space' as a political category: owned, distributed, mapped, calculated, bordered and controlled' $(2010,810)$. The state's territorial claim is central to these transformations. Territory is something 'shaped by and a shaper of, continual processes of transformation, regulation and governance' (Elden 2013, 13). Thus Lövbrand and Stripple (2006) note the simultaneous 'deterritorialisation and reterritorialisaton of the climate as political space' (sic, 218), at once treated as a 'global' issue and locked into national territories by the spatially explicit patterns of carbon sequestration and accounting. Braun $(2000,28)$ describes how geology 'rendered the space of the Canadian state vertical' at the end of the nineteenth century: not just an extensive and primarily agricultural territory, but a territory with depth. 
However, under the complex and contradictory processes of neoliberalization, conservation territorialization is no longer the preserve of the state. Non-state actors in the form of private and voluntary organisations (McCarthy and Prudham 2004; Hodge and Adams 2012) have become increasingly important agents, with the expansion of privately owned protected areas (Carter et al. 2008) and the growing capacity of conservation trusts (Dwyer and Hodge 1996). Non-state actors lead many large-scale conservation initiatives, even where they are linked to state-controlled protected areas. Thus in southern Africa, the Peace Parks Foundation has led the development of transfrontier conservation areas (Büscher 2010), while in Tanzania the African Wildlife Foundation has been a leading actor in the creation of wildlife management areas and conservation corridors around national parks (Goldman 2009, Sachedina 2010).

The ceding by governments of capability to define and regulate environmental territorialization has been far from straightforward or uniform, reflecting the complex hybridity of neoliberalization (Peck and Tickell 2002). The neoliberalization of conservation is characterised by complex processes of de-regulation and reregulation, and changing patterns of spatial demarcation and control over nature (McCarthy 2005; Büscher et al. 2012). It involves close collaboration between state and non-state actors as new commodities are created and traded in new markets (MacDonald 2010, Sullivan 2012, Pawlicezek and Sullivan 2011).

In this paper, we use the term territorialization to refer to the demarcation and mapping inherent in the creation of protected areas and areas of conservation concern, and re-territorialization to refer to changes in conservation's spatial claims. We consider a shift towards large-scale conservation in the UK as a form of reterritorialisation, a scalar shift in conservation narrative and practice, equivalent, for instance, to that between community, ecoregional and ecosystem-based approaches to marine management and conservation in Fiji (Sievanan et al. 2013). We identify the leading role of non-state actors in this process, but observe that the state remains central to the achievement of their aspirations through regulation and funding, particularly through the provision of agri-environment payments. In the next section, we analyse the origins and development of large-scale conservation thinking. 


\section{The idea of large-scale conservation}

Historically, spatial conservation strategies in the UK have been based on relatively small protected areas that held species or habitats of particular rarity or value (Sheail 1998). Until the end of World War Two, nature reserves were established privately on the whim of landowners interested in nature or by early conservation organisations such as the Royal Society for the Protection of Birds or the Society for the Promotion of Nature Reserves (Sheail 1976; Adams 2003). Growing calls for government involvement in conservation in the 1930s and 1940s separated the need for such small nature reserves to protect wildlife, from the protection larger landscapes for recreation and natural beauty. The legislation eventually passed in 1949 as the National Parks and Access to the Countryside Act enshrined this distinction in the work of the Nature Conservancy and the National Parks Commission and their successors (Sheail 1998). Nature (or 'wildlife' or most recently 'biodiversity') conservation in the UK centred on protection of mostly small sites through National Nature Reserves (owned or leased by the Nature Conservancy, or held under agreement with their owners) and Sites of Special Scientific Interest (essentially planning designations on private land).

However, even in the 1940s, there was recognition of the benefits of designating larger tracts of land for conservation. The Wildlife Conservation Special Committee, which met in parallel with the National Parks Committees as part of planning for post-war reconstruction in the UK (Huxley 1947) identified 35 extensive 'Scientific Areas' (Figure 1), 'tracts of country' deemed 'worthy of preservation' yet that did not require management as a part of a 'strictly controlled reserve' (Huxley 1947, para 206). Most were included among the 52 'Conservation Areas' identified by the government's National Parks Committee. In the event, neither Conservation Areas nor Scientific Areas were introduced under the 1949 Act.

\section{[Figure 1 HERE]}

Various factors influenced this failure to designate large nature conservation areas in the 1940s. First, in the immediate post-war period the imperative for economic security, and the high priority of domestic production of food and timber (e.g. the 
Forestry Commission afforestation plans, Sheail 1976), mitigated against large territorial claims for conservation. Second, landowners (and county councils where they were strongly represented) retained influence over rural affairs, as the opposition to the new Nature Conservancy in the 1950s attested (Sheail 1998). Third, there was a lack of flexible institutional arrangements that could have facilitated co-ordination of land uses and management at a landscape scale without large-scale public land acquisition. The options available to government at the time were limited to the capacity to prevent development through the planning system (SSSIs) and the potential to acquire land for nature reserves (NNRs). Neither of these was suitable for the management of large conservation areas.

In the 1980s, conservation policy began to address what was then termed the 'wider countryside' outside nature reserves (Adams et al. 1992; Adams 2003). By that time, the damage to species and ecosystems caused by post-war agricultural intensification was clear, and fiercely debated. From 1981 a regime of costly management agreement payments was in place to compensate landowners for the profits foregone from protecting SSSIs. Patterns of public demand on the countryside had begun to change, with a shift in balance from agricultural products to non-agricultural public and private benefits such as recreation, natural beauty and biodiversity (Lowe et al. 1994). The post-war separation between scientific conservation, achieved primarily through nature conservation sites, and the conservation of scenic and recreation values, achieved through more extensive countryside designations, the so-called 'great divide' (Sheail 1988), began to blur. It was officially bridged by the merging of government conservation agencies in Wales and Scotland in 1990 and in England with the merger of the Countryside Agency and English Nature to form Natural England in 2006. These mergers forced distinct cultures of conservation together, and may have contributed to larger or 'landscape' scale thinking on the part of those responsible for biodiversity conservation.

Agricultural surpluses generated under the support of the Common Agricultural Policy (CAP) catalysed this wider view of conservation, providing a rationale for a reduction of the intensity of agricultural production. The shift of CAP funding from support for production towards direct payments and agri-environment programmes provided space and resources for more ambitious approaches to biodiversity 
conservation. Payments by the state to private landholders, including conservation trusts, through agri-environment funds become an important element in conservation strategies in the wider countryside (Kleijn and Sutherland 2003; Swetnam et al. 2004). However, concern about species and habitat loss persisted: in England, 18 out of 42 priority habitats and 120 out of 390 priority species were in decline in 2008 (DEFRA 2011a, 9). Agri-environment schemes were extensive in coverage and expensive, but seemed of limited effectiveness in protecting biodiversity (Kleijn and Sutherland 2003; Kleijn et al. 2006).

These policy experiments in conservation incentive payments at farm and landscape scale were increasingly informed by developments in scientific ideas about the ecology of landscapes and areas of habitat within them. From the 1960s, there was recognition of the implications of research on island biogeography for small isolated areas of habitat and nature reserves (Moore 1962; Diamond 1975; Terborgh 1976). The development of landscape ecology (Forman and Godron 1986), a growing literature on the connections between ecosystem fragments (Lindenmayer and Fischer 2006; Crooks and Sanjayan 2006), and on the ecology of linked or 'meta' populations (Southwood 1977; Hanski 1999) provided the scientific basis for the idea that conservation should be pursued through protected areas understood as part of 'ecological networks' (e.g. Jongman 1995; Jongman and Pungetti 2004). The idea of conservation 'networks' was particularly favoured by those considering how conservation action should take account of anthropogenic climate change (Thomas et al. 2007). Hopkins et al. $(2007,10)$ emphasised the importance of 'ecologically resilient and varied landscapes', and 'ecological networks' in a conservation response to climate change in England.

Although Lindenmayer et al. (2008) found little consensus on general principles for landscape conservation, the 'landscape' approach was widely taken up in the UK in the new Millennium. Hughes and Brooks (2009) set out an agenda for conservation at 'an ecosystem scale' in Scotland. The report of the Lawton committee, Making Space for Nature (Lawton et al. 2010), strongly endorsed the landscape approach.

Informed by this changing scientific agenda, conservationists began to focus on the idea of reversing decades of habitat loss and deterioration through bold creative 
conservation and ecological restoration. Thus Colston (1997) called for large-scale restoration as a response to a conservation 'black hole' in the counties of east and central England, which had anomalously low proportions of SSSIs. Large restoration schemes began to be developed, for example in East Anglia at Wicken Fen and Great Fens (Colston 2003). The idea of restoration of lost nature became a key factor in the emerging thinking about large-scale conservation by non-governmental conservation organisations.

Government conservation also took a creative and restorative approach aimed at large areas. In 2008, Natural England published 'a new framework for delivering priority habitats and species in England', building on the Biodiversity Action Plan. This proposed adoption of 'an ecosystem approach' and set out to 'achieve biodiversity enhancements across whole landscapes and seascapes' (England Biodiversity Group 2008, 5). Natural England went on to develop eight 'Integrated Biodiversity Delivery Areas', representing 'entire landscapes' (Natural England 2008). Making Space for Nature (Lawton et al. 2010) built on these initiatives, recommending the creation of a series of 'Ecological Restoration Zones', operating 'over large, discrete areas within which significant enhancements of ecological networks are achieved, by enhancing existing wildlife sites, improving ecological connections and restoring ecological processes' (Lawton 2010, 70).

The ambition of restoration as a conservation strategy was also reflected in growing enthusiasm for the idea of restoring the element of the 'wild' in the UK's severely transformed landscapes (Adams 2003; McFarlane 2007). Conservationists began to focus on the idea of 'wild land', where 'human intervention is minimal and natural processes are respected' (Taylor 2005, 14.), and on processes of 'rewilding' (e.g. Buller 2004; Taylor 2005; Jeeves 2006; Ward et al. 2006; Cairns and Hamblin 2007; Brown et al. 2011). British conservation looked to bold projects elsewhere, notably Oostvaardesplassen in the Netherlands, where ecosystems in a former polder were grazed by effectively un-managed herds of large herbivores (Taylor 2005; Vera 2009), and to the work of the Rewilding Institute and other thinking in the USA (e.g. Foreman 2004). Several large conservation projects in the UK began to focus on restoration of ecosystem function or 'wildness', for example Ennerdale in Cumbria 
(Browning and Yanik 2004), and Wicken Fen in Cambridgeshire (Hughes et al. 2011).

\section{Large Conservation Areas in the UK}

In order to assess the significance of these ideas of large-scale conservation in the UK, we undertook a survey of Large Conservation Areas (LCAs) being developed by non-governmental conservation organisations in 2011. We defined LCAs as 'areas where an organisation or partnership directs land use change within a delineated area to achieve ecological restoration for wildlife conservation, and where public benefits are explicitly recognised in management aims'. We set an arbitrary minimum size for our LCAs (500 ha or $5 \mathrm{~km}^{2}$ ) to exclude conventional nature reserves. We included large private estates with a clear and explicit emphasis on conservation management, but excluded estates held or managed solely by government or public bodies (e.g. Forestry Commission or Defence Estates), whose management objectives were hard to confirm. Unlike Macgregor et al. 2012, we also excluded government zonation schemes, whether protected areas with special planning controls (e.g. National Parks, Areas of Outstanding Natural Beauty, Green Belts) or area-based land management incentive schemes (e.g. Higher Level Stewardship target areas, Catchment Sensitive Farming Initiative, Scotland Rural Development Programme), since we wished to focus on active attempts to direct change and judged these too open-ended to meet our criteria.

We took data from public websites describing three well-known programmes of largescale conservation: Living Landscapes (Wildlife Trusts), Futurescapes (RSPB 2010), and Landscape Target Areas (Butterfly Conservation, Ellis et al. 2012). We used telephone and email discussions to clarify and supplement data, and a snowball approach to extend coverage to other conservation NGOs in England and Scotland (John Muir Trust, Wildfowl and Wetlands Trust, National Trust for Scotland, Woodland Trust). The database and a preliminary analysis were shared with all respondents. Sites with insufficient data were excluded from the analysis: our results are therefore minimum figures. 
By 2011, most landowning conservation NGOs in the UK had established LCA programmes. The National Trust, with a substantial existing landholding of large estates, began to think explicitly about landscape scale conservation around the time of their centenary in 1995 (Harvey 1995); the Wicken Fen Vision project was officially launched in 1999, a hundred years after the first strip of fen was acquired by the Trust. The RSPB proposed the development of 'Futurescapes' in 2001, arguing that action was needed at a larger scale than the historical protected area approach, which had failed to halt the overall decline of biodiversity (RSPB 2001). In 2002, the Woodland Trust (2002) published a report on 'landscape scale action for woodland biodiversity'; Butterfly Conservation published its ideas about landscape-scale conservation three years later (Bourn and Bulman 2005). The Wildlife Trusts 'Living Landscapes' programme was launched in 2005 (Wildlife Trusts 2011), and the RSPB re-launched a rejuvenated 'Futurescapes' programme in 2010, hoping to 'achieve a step change in sustainable countryside management... at a scale capable of making a real difference' (RSPB 2010, 23).

Overall, in our survey we found a total of 244 projects across the UK: $72 \%$ in England, 19\% in Scotland, 6\% in Wales and 2\% in Northern Ireland (one project crossed the English/Scottish border, The Tweed Catchment Plan). The number of Scottish projects was almost certainly underestimated, reflecting the lack of information on the conservation intentions of large estates (Adams 2012).

In total, 18 different organisations led LCA Projects (if the 42 Wildlife Trusts are collectively considered to be one organisation). The vast majority ( $86 \%$ ) were led by three organisations, the Wildlife Trusts (46\%), Butterfly Conservation (24\%), and RSPB (16\%), although our methods may well mean that we missed a larger proportion of projects led by other organisations. Other key organisations included the National Trust, John Muir Trust, National Trust for Scotland, and the Woodland Trust.

LCAs are highly diverse in their aims, embracing a mix of ecological restoration, creative conservation and work with landowner stakeholders. Thus the Wildlife Trusts' 'Living Landscapes' programme aims to 'restore the UK's battered ecosystems, for wildlife and people', 'restoring, recreating and reconnecting wildlife 
rich spaces in rural and urban areas' (Wildlife Trusts 2011, 2). Butterfly

Conservation's 'Landscape Target Areas', chosen for their importance for threatened butterfly and moth species, focus on the restoration of networks of sites, improving occupied and unoccupied habitat fragments, and improving connectivity between patches (Ellis et al. 2012). While most projects are recent in their present form, many are built around much older (and smaller) nature reserves, and the knowledge, logistics and local relationships built up over time. Thus most of the 120 Wildlife Trusts' Living Landscape projects have been created around the extended network of 2,250 (mostly small) existing nature reserves owned or managed by individual county Wildlife Trusts. Most of the RSPB Futurescapes also have established nature reserves at their core, as do schemes such as the National Trust's Wicken Fen Vision and Wild Ennerdale.

Large-scale projects involved a wide diversity of actions to achieve their conservation goals. Almost three quarters of projects involved improving existing sites (73\%), and about half involved improving the wider countryside (55\%), or 'physically linking sites' (47\% of projects). These actions are usually combined: thus the RSPB combines four forms of action in its Futurescapes: site expansion or creation, physical linkages, softening the 'matrix' (land management that is more sympathetic to biodiversity conservation), and buffering wildlife sites from external pressures (Symes et al. 2011). Butterfly Conservation also mixes methods, advising landowners and encouraging the uptake of grant schemes, undertaking direct management through project officers, and arranging surveying and monitoring through volunteers.

The most striking feature of these LCAs, however, is their overall spatial extent. Our search did not attempt the challenge of mapping precise area boundaries (see Macgregor et al. 2012). Many initiatives overlap, with different organisations having competing projects in the same areas. Thus Macgregor et al. describe the multiple overlaps in the Nene Valley, of an RSPB 'Futurescape', a Wildlife Trust 'Living Landscape', as well as a Higher Level Stewardship agri-environment scheme. However, those LCAs we surveyed covered nearly 6 million ha, equivalent to about one third of the total land area in the UK. The mean size of all UK projects was 25,590 ha, with 83 projects over 10,000 ha and 8 projects over 100,000 ha (Figure 2). 


\section{[Figure 2 here]}

\section{Conservation Re-territorialization and Conservation Trusts}

The re-territorialization of conservation in the UK represented by the newly created networks of LCAs is the physical evidence of the growth in reach and ambition of non-governmental conservation organizations (Armsworth et al. 2012). Conservation trusts have an important role in creating institutional frameworks for the delivery of conservation (Dwyer and Hodge 1996), bringing together networks of public and private actors to collaborate in large-scale conservation schemes (Logan and Wekerle 2008). Since 1990, the land holdings of the three largest UK conservation trusts have grown by some 20 per cent, although some have grown faster (e.g. the Wildlife Trusts by nearly 50 per cent), while younger organisations such as the John Muir Trust have also expanded their conservation land holdings. LCAs reflect a growth of conservation authority and capacity, as well as the importance of bold and positive messaging to public profile and associated fundraising.

This growth in the power and reach of conservation trusts has taken place as neoliberal strategies have gained ground in biodiversity conservation (Lockie and Higgins 2007; Brockington et al. 2008; Büscher et al. 2010). NGOs have begun to take over the lead in the direction of biodiversity planning from the state. Governance strategies based on public-private partnership have been seen to combine the benefits of 'small government' with the empowerment of communities and the democratic benefits of local action (McCarthy 2005, Lockie and Higgins 2007). In the UK, conservation strategies based on land purchase and regulation by the state have been progressively supplemented since the 1980s by more plural strategies based on various kinds of partnerships between state, private sector and non-governmental organizations.

In the context of a neoliberal era of 'small government', NGOs have come to play a key role in the coordination of private landowners to deliver conservation outcomes. The kind of mixed approach to conservation governance, in which state and private actors engage under broad processes of neoliberalization, can be characterised in terms of 'institutional blending' (Hodge and Adams 2012). Among the elements of 
institutional blending are: 1) the formal legal transfer of ownership between different property regimes and between different categories of owner; 2) the decomposition of property into separate property rights and their subsequent reassignment amongst different agents; 3 ) the shaping of incentives for land management; and 4) the evolution of informal arrangements for internal governance and partnerships (Hodge and Adams 2012). The operation of large-scale conservation territorializations relies heavily on these elements.

However, the state has sought to retain a position as a key actor in the promotion of cross-sector conservation partnerships. These sit alongside, in some cases overlapping with, the NGO-led large conservation initiatives discussed above. The government wishes to direct land use change and management in support of its vision to restore ecosystems across the country (DEFRA 2011a, 15), but rather than intervene directly in order to achieve this outcome, it has sought to incentivise others. This move is revealed by two specific initiatives proposed in the 2011 White Paper, Local Nature Partnerships (LNPs) and Nature Improvement Areas (NIAs).

Local Nature Partnerships were conceived as growing from the bottom-up, established 'where local areas wish to establish them', and with a strongly communitarian role, aiming to 'engage and win the support of the local people and communities they serve' (DEFRA 2011a, 19-20). LNPs were intended to co-ordinate actions across individual organisations, 'aligning efforts and making the best use of resources'. Partnerships that were 'recognised' by government would be eligible for financial support from a one-off fund worth $£ 1$ million in 2011/12. Indeed, the idea of LNPs was strongly promoted within DEFRA by conservation NGOs. LNPs reflected their approach to existing LCAs: the Wildlife Trusts emphasised the importance of partnership with 'local communities, landowners, schools and businesses' in Living Landscapes (Wildlife Trusts 2011), and the RSPB described their Futurescapes as rooted in partnerships with other environmental organisations, local communities, businesses and government bodies (RSPB 2010).

The hand of government was more strongly expressed in Nature Improvement Areas. These drew on the same rhetorical frame, proposed for establishment by 'partnerships of local authorities, local communities and landowners, the private sector and 
conservation organisations', based on 'a local assessment of opportunities for restoring and connecting nature on a significant scale' (DEFRA 2011a, 21).

Government provided $£ 7.5$ million to support the creation of 12 initial NIAs as seed funds: partners would be expected to pool resources and draw together funding from a variety of sources, such as the National Lottery, environmental charities, business, local authorities and communities. A competitive bidding process was organised, with government support targeted to NIAs 'where joint priorities have been agreed which meet national and local needs' (DEFRA 2011a, 21).

The successful NIAs were announced in February 2012 (DEFRA 2012; Figure 3). They ranged from peri-urban environments such as the Birmingham and Black Country NIA, a partnership of over 50 organisations involved in Birmingham, Dudley, Sandwell, Walsall and Wolverhampton, to the Marlborough Downs NIA on chalk downland south of Swindon, which was 'farmer-led', a 'bottom-up approach' that its organisers hope will lead to "far greater and more wide-reaching benefits as a result of the "ownership" conferred on us by this project' (Natural England 2013). Nonetheless, the aggregate area within NIAs remains relatively small compared to the much large area within the numerous NGO-led LCAs.

\section{[Figure 3 here]}

The interaction between government, landowners and private conservation trusts is critical to this new landscape approach to conservation. The challenge for government conservation in an era of neoliberalization is how to ensure appropriate management of land under different ownerships for a sufficiently long period of time to secure substantial biodiversity gains? In the UK, government remains explicit in its wish to retain control of land already designated for conservation: the White Paper comments that 'special protection of sites that are especially rich in wildlife or particularly fragile must continue' (DEFRA 2011a, 10). However, the reterritorialization of conservation represented by large-scale conservation initiatives in the UK involves a shift in the balance of public and private in the delivery of conservation outcomes. 
Large conservation areas demand a new scalar politics of conservation, and in the UK, NGOs are at its heart. The coordination of the actions of diverse governmental and private landowners and interests across large areas is difficult (Anon 2011). Critical factors are the level of control needed to achieve conservation outcomes, the opportunity and transaction costs of imposing it, and the security of the management regime established in the long term. Collaboration among landholders to achieve conservation raises important issues of collective action (Ostrom 1990; Hodge and McNally 2000; Franks and McGloin 2007), particularly where conservation agents interact with other private and state actors (e.g. commercial agricultural land owners, other private landholders in local communities, water companies, Internal Drainage Boards, the Forestry Commission or the Environment Agency).

The choices made by NGOs about LCA project areas, and of management approaches within them, are the outcome of their own internal decision-making processes and the willingness of others to become involved in partnership arrangements. There can be no guarantee that the collective outcome of these organisations' decisions represents the 'best' outcome when looked at from a broader social perspective. These decisions are not driven by market incentives alone, and the NGOs are not democratically accountable. Sandberg (2007) identifies the paradox between the doctrine of a 'lighter state' (and associated fragmentation of government) and the 'new heavy scientific paradigms of sustainable nature resource management', which would appear to demand a sovereign state 'in full command of both its territory and its extractive sectors' (Sandberg 2007, 614).

LCAs rely on a wide range of approaches, including land ownership, conservation covenants and various kinds of informal engagements with private owners (c.f. Hodge 2001). Partnerships to create such projects involve complex mixes of public and private interests, and novel patterns of state regulation and payments. Fairfax et al. (2005) trace the growing complexity of patterns of land ownership and control in the USA, and particularly the importance of easements over land, which separate ownership from control of particular land development rights. This pattern also holds for the UK. Most LCA projects have multiple partners, of a wider range of kinds (Table 1): only $12 \%$ of projects ( 29 of those sampled) were implemented by one organization alone. Partners included central government departments, non- 
departmental public bodies, local authorities, private businesses, non-profit organisations or charitable trusts, educational institutions, and utility companies. The most diverse category of partners was non-governmental organisations, with many of the lead organizations involved in LCAs collaborating with each other in complex projects sometimes with overlapping (but not identical) spatial extent and branding.

\section{[Table 1 HERE]}

\section{Neoliberal Conservation Landscapes}

A central framing device for the large conservation areas being developed by NGOs in the UK is the concept of ecosystem services. The Department for Environment, Food and Rural Affairs (DEFRA) embraced the Convention on Biological Diversity's 'ecosystem approach' early in the new Millennium. However, of the 12 'principles' in the approach, one dominated UK thinking: Principle 5 'conservation of ecosystems structure and function to provide ecosystem services should be a priority' (CBD 2013; Pound 2009).

The construction of nature as a 'service provider' has had a profound effect on thinking about conservation in the UK, as internationally. Although challenged (e.g. McCauley 2006; Redford and Adams 2009), the concept of ecosystem services has been widely adopted, notably in the Millennium Ecosystem Assessment in 2005, and TEEB (The Economics of Ecosystems and Biodiversity, MacDonald and Corson 2012). Originally conceived as a way of explaining (and ensuring conservation of) the values of nature, ecosystem services have become the basis of technocratic environmental management, sustaining and not challenging entrenched excesses of production and consumption (Norgaard 2010).

In the context of large conservation areas, the concept of ecosystem services works to build a rhetorical bridge to profit-orientated private landowners, and to cash-strapped neoliberally minded local and national government. It positions conservation not as constraining the economy, but as protecting a source of direct economic value. Two thirds of the descriptions of projects surveyed mentioned promotion of cultural ecosystem services as a project purpose (including the improvement of access to 
nature, recreation and health benefits, sustainable tourism, preservation of scenic beauty, culture, and natural and historic heritage). One third mentioned regulating ecosystem services (improvement of water quality and storage, flood risk management, soil erosion control, carbon storage and improvement of habitat for pollinators). Twenty one per cent of projects aimed to 'support the local economy or employment', and eight per cent listed 'provisioning ecosystem services', such as timber and sustainable local food production, as a conservation purpose.

The concept of ecosystem services has a central place in the techniques by which nature is rendered visible to the market (Robertson 2006; MacDonald and Corson 2012), commodified and financialized though monetisation and marketization (Robertson 2004; Pawlicezek and Sullivan 2011, Sullivan 2012). We noted above that the re-territorialization of conservation within a large-scale landscape frame has accompanied a significant neoliberal shift within conservation thought and practice. Indeed, we would argue that it depends on and furthers the neoliberalization of conservation itself, and the attempt to promote conservation in and through the expansion of capitalism (Igoe and Brockington 2007; Brockington et al. 2008; Brockington and Duffy 2010). Büscher et al. $(2012,23)$ argue that conservation should be understood as a set of governmentalities that involve the extension of 'profitable commodification processes' by extending and policing separation between human society and non-human nature. So, while conservation might seem to be about 'saving nature', it actually serves 'to entrain nature to capitalism' (Büscher et al. 2012, 7).

The UK National Ecosystem Assessment (NEA) was published just a month before the UK White Paper (UK NEA 2011). The idea of 'ecosystem services', used as a way of measuring the value of nature and determining choices about land use, now lies at the core of government environmental policy-making and delivery (DEFRA 2007; Hopkins 2013). Commitments in the White Paper led to establishment of Ecosystem Markets Task Force 'to review the opportunities for UK businesses from expanding green goods, services, produces, investment vehicles and markets which value and protect the environment' (DEFRA 2013a), and creation of a Natural Capital Committee, reporting to the Chancellor of the Exchequer (DEFRA 2013b). 
Biodiversity conservation in the UK has been re-framed to fit this idea of nature. The 2011 White Paper expressed the need to protect 'our most precious and endangered wildlife', by 'working together to safeguard ecosystem services and restore ecosystems through more cost-effective and integrated approaches' (DEFRA 2011a, 17). Natural England commissioned extensive research on the impacts of changing land use and management in the uplands on the delivery of ecosystem services and benefits (Natural England 2009). The UK's Post-2010 Biodiversity Framework emphasised the importance of 'building and applying the evidence base to implement the ecosystem approach and support ecosystem assessment' (JNCC and DEFRA 2012, 7).

\section{Conclusions}

The involvement of NGOs in the development of large-scale conservation projects in the UK undoubtedly represents a significant transition in conservation ambition. The new territorialization involved in these extended and networked claims for biodiversity take a range of forms, and involve new combinations of actors, including the state and private landowners as well as NGOs. Large conservation projects in the UK will trigger a new politics of engagement and dispute at a number of levels and different arenas of planning and governance, as has happened elsewhere (e.g. Büscher 2010, Sachedina 2010).

It is not clear whether landscape scale conservation projects provide the level of control of land use change necessary to secure intended conservation outcomes in the face of present and future changes, or whether they are resilient enough to secure those outcomes in the long term in the face of economic, social and climate change and the increased pressures on land use that are likely to be associated with them.

The sustainability of the conservation outcomes of these new large projects is hard to predict. It depends on a range of factors, including the changing rural economy and agricultural profitability, changing policy context, changing planning goals (housing, flooding, climate change). In particular, the future development of the Common Agricultural Policy (European Commission 2013), and particularly agri-environment policy, will shape the framework for conservation as an element in rural land 
management in the UK (Hodge 2013). The success of large conservation projects will also be affected by public demands on the countryside. Many existing projects claim broad public benefits and local support (e.g. Wildlife Trusts 2007; RSPB 2010). Such claims will be tested. While changes to the management of individual small conservation sites may have relatively limited impacts on the wider character of local landscape or local economic opportunity, the development of a landscape scale project has wider implications. The interface between the NGOs leading LCAs and processes of public spatial planning is important. The development of ecosystem and biodiversity values requires a long-term commitment to particular land uses which may not generate the highest financial return or which may change the balance of local economic activity. Local public support might wane in the face of impacts on local people, changes to familiar landscapes or competing demands for land.

The fundamental feature of large conservation areas is that they are an attempt to coordinate land use and conservation management over a larger extent than can typically be maintained by a single conservation landholder (governmental or nongovernmental), or by a single private owner or manager responding to conservation management agreements or agri-environment payments. Large scale conservation potentially demands novel institutional architectures, which blend categories of governmental and private tenure and management (Hodge and Adams 2012). Hybrid institutions, emerging through the work of evolving partnerships between state and non-state actors, involve on a range of governance tools, including novel marketbased mechanisms to secure biodiversity, targeted payments by the state to landowners and market and biodiversity-friendly regulation (Pawliczek and Sullivan 2010, Büscher et al. 2010, MacDonald and Corson 2012). In the UK, the key instrument for government is the agri-environment scheme, which underpins the funding model of many large conservation areas.

Shucksmith and Ronningen (2011) suggest that the financial crisis of 2008 might open opportunities to re-imagine and rebuild a place for small farms in Europe. The same hiatus may offer opportunities for creative approaches to the delivery of public benefits from nature through large-scale conservation initiatives. The potential of hybrid strategies and institutional bricolage to transform and extend patterns of conservation territorialisation are potentially profound. 
However, there are limits to what may be achieved by non-state actors under existing legal institutions and incentives, and in an era of post-crisis neoliberalism (Peck et al. 2010). Governments cannot simply slough off responsibility for LCAs to the 'Big Society', however well the dependence of biodiversity conservation on partnerships seems to fit the model (Natural England 2011). The formal mechanisms required to ensure the long-term sustainability of conservation gains in LCAs may require government to take an active role in steering social and economic processes towards publicly desired outcomes, and acting as a countervailing force against the market incentives. Neoliberalism may offer a new set of mechanisms in pursuing conservation ends, but also creates new risks and challenges. The achievement of public conservation goals would seem to continue to require an active and interventionist government. It is here, in the balance of public and private interest and the question of who exercises power to strike that balance, that analytical and policy attention should focus. 


\section{References}

Adams W M 2003 Future Nature: a vision for conservation Earthscan, London Adams W M 2004 Against Extinction: the story of conservation, Earthscan, London Adams W M 2012 Private and networked: large conservation areas in Scotland', Ecos 33 (3/4) 124-33

Adams W M Hodge I D and Bourn N A D 1992 Conservation in the wider countryside: SSSIs and wildlife habitat in Eastern England Land Use Policy 9 235-248

Anon 2011 Think big Nature 469131

Armsworth P R, Fishburn I S, Davies Z G, Gilbert J, Leaver N and Gaston K J 2012 The size, concentration and growth of biodiversity conservation nonprofits BioScience 62 271-281

Arsel, M and Büscher B 2012 Nature $^{\mathrm{TM}}$ Inc: changes and continuities in neoliberal conservation and environmental markets Development and Change 43 53-78.

Balmford A 2012 Wild Hope: on the front lines of conservation success, Chicago University Press, Chicago Ill.

Bear C 2012 Assembling the sea: materiality, movement and regulatory practices in the Cardigan bay scallop fishery', Cultural Geographies 20: 21-41

Bourn N A D and Bulman C R 2005 Landscape scale conservation: theory into practice, Kuhn E, Feldmann R, Thomas J A and Settele J eds, Studies on the ecology and Conservation of Butterflies in Europe, Vol.1: General Concepts and Case Studies, Butterfly Conservation, Wareham, Dorset, 111-12

Braun B 2000 Producing vertical territory: geology and governmentality in late Victorian Canada Ecumene 7 7-46

Brockington D and Duffy R 2010 Capitalism and conservation: the production and reproduction of biodiversity conservation Antipode 42 469-84

Brockington D, Duffy R and Igoe J 2008 Nature Unbound: Conservation, Capitalism and the Future of Protected Areas Earthscan, London

Brosius J P and Russell D 2003 Conservation from above: an anthropological perspective on transboundary protected areas and ecoregional planning, Journal of Sustainable Forestry 17 39-65

Brown C, Mcmorran R and Price M F (2011) Rewilding - a new paradigm for nature conservation in Scotland? Scottish Geographical Journal 4 288-314 
Browning G and Yanik R 2004 Wild Ennerdale: letting nature loose Ecos: A Review of Conservation 25(3/4) 34-8

Bryant R L 2002 Non-governmental organizations and governmentality: 'consuming' biodiversity and indigenous people in the Philippines Political Studies 50 268-92

Buller H 2004 Where the wild things are: the evolving iconography of rural fauna Journal of Rural Studies 20 131-141

Büscher B 2010 Seeking telos in the 'transfrontier': Neoliberalism and the transcending of community conservation in southern Africa Environment and Planning A $42644-\bullet 660$.

Büscher B, Sullivan S, Neves K, Igoe J and Brockington D 2012 Towards a synthesized critique of neoliberal conservation. Capitalism, Nature, Socialism 23 4-30

Cairns P and Hamblin M 2007 Tooth and Claw: living alongside Britain's predators Whittles Publishing, Dunbeath

Carter E, Adams W M and Hutton J 2008 Private protected areas: management regimes, tenure arrangements and protected area categorization in East Africa Oryx 42 177-18

Castree N 2008 Neoliberalising nature: the logics of deregulation and reregulation. Environment and Planning A 40 131-152

CBD 2010 Aichi Biodiversity Targets, http://www.cbd.int/sp/targets (accessed 17 April 2013)

CBD 2103 Ecosystem Approach Principles http://www.cbd.int/ecosystem/principles.shtml (accessed 26 April 2013)

Cernea M M and Schmidt-Soltau K 2006 Poverty risks and national parks: policy issues in conservation and resettlement. World Development 34 1808-1830.

Chape S, Harrison, J, Spalding, M, and Lysenko I 2005 Measuring the extent and effectiveness of protected areas as an indicator for meeting global biodiversity target Philosophical Transactions of the Royal Society B 360 443-455

Colston A 1997 Conserving wildlife in a black hole Ecos: A Review of Conservation 18(1) $61-7$

Colston A 2003 Beyond preservation: the challenge of ecological restoration in Adams W M and Mulligan M eds Decolonizing Nature: strategies for Conservation in a post-colonial era Earthscan, London 247-267 
Crooks K R and Sanjayan M 2006 eds Connectivity Conservation Cambridge University Press, Cambridge

DEFRA 2007 Securing a healthy natural environment: An action plan for embedding an ecosystems approach. Department for Environment Food and Rural Affairs, London.

DEFRA 2011a The Natural Choice: securing the value of nature Natural Environment White Paper, www.defra.gov.uk/environment/natural/whitepaper/, accessed 13 October 2011.

DEFRA 2011b Department for Environment Food and Rural AffairsWebsite: http://www.defra.gov.uk/news/2011/06/07/natural-environment/, accessed 13 October 2011

DEFRA 2012 http://www.defra.gov.uk/news/2012/02/27/nature improvement area/ (accessed 13 April 2012)

DEFRA 2013a Realising Nature's Value: the Final Report of the Ecosystem Markets Task Force, Ecosystem Markets Task Force, DEFRA, London (www.defra.gov.uk/ecosystem-markets/)

DEFRA 2013b Natural Capital Committee, (http://www.defra.gov.uk/naturalcapitalcommittee/, accessed 12 August 2013.

Diamond J M 1975 The island dilemma: lessons of modern biogeographic studies for the design of nature reserves. Biological Conservation 7 129-146

Dowie M 2009 Conservation Refugees: The hundred-year conflict between global conservation and native peoples, MIT Press, Cambridge MA

Dressler W and Büscher B 2008 Market triumphalism and the so-called CBNRM "crisis" at the South African Section of the Great Limpopo Transfrontier Park Geoforum $39452 \cdot \bullet 465$

Duffy R 2006 The potential and pitfalls of global environmental governance: The politics of transfrontier conservation areas in Southern Africa Political Geography 25 89-112

Dwyer J C and Hodge I D 1996 Countryside in Trust: land management by conservation, recreation and amenity organizations Wiley, Chichester

Elden S 2010 Land, terrain, territory Progress in Human Geography 34 799-817

Elden S 2013 How should we do the history of territory? Territory, Politics, Governance 1 1-16. 
Ellis S, Wainwright D, Berney F, Bulman C and Bourn N 2011 Landscape-scale conservation in practice: lessons from northern England, UK Journal of Insect Conservation 15 69-81

Ellis, S Bourn N A D and Bulman C 2012 Landscape-scale Conservation for Butterflies and Moths: lessons from the UK, Butterfly Conservation, Wareham, Dorset

England Biodiversity Group 2008 Securing biodiversity: a new framework for delivering priority habitats and species in England, Natural England, Sheffield.

England Biodiversity Group 2011 Think Big: how and why landscape-scale conservation benefits wildlife, people and the wider economy Natural England, Report NE309

European Commission 2013 CAP Reform - an explanation of the main elements, MEMO/13/621 European Commission, Brussels

Fairfax S, Gwin L, King M A, Raymond L and Watt L A 2005 Buying Nature: the limits of land acquisition as a conservation strategy, 1780-2004 MIT Press, Cambridge Mass

Fairhead J and Leach M 2003 Science, Society and Power: environmental knowledge and policy in West Africa and the Caribbean, Cambridge University Press, Cambridge

Foreman D 2004 Rewilding North America: A Vision for Conservation in the $21^{\text {st }}$ Century Island Press, Washington

Forman R T T and Godron M 1986 Landscape Ecology Wiley, New York

Franks J and McGloin A 2007 Environmental co-operatives as instruments for delivering across-farm environmental and rural policy objectives: Lessons for the UK Journal of Rural Studies 23 472-489

Futerra 2010 Branding Biodiversity - the new nature message, Futerra Sustainability communications, http://www.futerra.co.uk/blog/branding-biodiversity, accessed 16 April 2013.

Goldman M 2009 Constructing Connectivity: Conservation Corridors and Conservation Politics in East African. Rangelands, Annals of the Association of American Geographers 99 335-359.

Hanski I 1999 Metapopulation Ecology Oxford University Press, Oxford

Harvey H J 1995 The National Trust and nature conservation: prospects for the future. Biological Journal of the Linnean Society 56 Suppl. 231-248 
Hodge I D 2001 Beyond agri-environmental policy: towards an alternative model of rural environmental governance Land Use Policy 18 99-111

Hodge I D 2013 Agri-environment policy in an era of lower government expenditure: CAP reform and conservation payments Journal of Environmental Planning and Management 56 (2) 254-70

Hodge I D and Adams W M 2012 Neoliberalization, rural land trusts and institutional blending Geoforum 43 (3) 472-482

Hodge I D and McNally S 2000 Wetland restoration, collective action and the role of water management institutions Ecological Economics 35 107-1

Holdgate M 1999 The Green Web: a union for world conservation, Earthscan, London.

Hopkins J 2013 Nature conservation in the early $21^{\text {st }}$ century: all change? British Wildlife 24 183-189

Hopkins J J, Allison H M, Walmsley C A, Gaywood M and Thurgate G 2007 Conserving Biodiversity in a Changing Climate: guidance on building capacity to adapt (PB12597) Department for Environment, Food and Rural Affairs.

Hughes D M 2005 Third Nature: Making Space and Time in the Great Limpopo Conservation Area Cultural Anthropology 20 157-184.

\section{Hughes F M R, Stroh P Adams W M, Kirby K, Mountford $J O$ and Warrington}

S 2011 Monitoring and evaluating large-scale, open-ended habitat creation projects: a journey rather than a destination Journal for Nature Conservation 19 245-253

Hughes J and Brooks S 2009 Living Landscapes: towards ecosystem-based conservation in Scotland, Scottish Wildlife Trust, Edinburgh.

Huxley J 1947 Conservation of Nature in England and Wales: Report of the Wildlife Conservation Special Committee (England and Wales) HMSO Cmd. 7122.

Igoe J and Brockington D 2007 Neoliberal conservation: a brief introduction. Conservation and Society 45 432-449

Jeeves M 2006 'Rewilding Middle England Ecos: A Review of Conservation 27 (3/4) 8-16

JNCC and DEFRA 2012 UK Post-2010 Biodiversity Framework Joint Nature Conservation Committee, Peterbough

Jongman R H G 1995 Nature conservation planning in Europe: developing ecological networks Landscape and Urban Planning 32 169-83 
Jongman R H G and Pungetti G 2004 eds Ecological Networks and Greenways: Concept, design, implementation Cambridge University Press, Cambridge

Kleijn D and Sutherland W J 2003 How effective are European agri-environment schemes in conserving and promoting biodiversity? Journal of Applied Ecology $40947-969$

Kleijn D,. Baquero R A, Clough Y, Díaz M, De Esteban J, Fernández F, Gabriel D, Herzog F, Holzschuh A, Jöhl R, Knop E, Kruess A, Marshall E J P, Steffan-Dewenter I, Tscharntke T, Verhulst J, West T M and Yela J L 2006 Mixed biodiversity benefits of agri-environment schemes in five European countries Ecology Letters 9 243-254

Ladle R J and Whittaker R J eds 2011 Conservation Biogeography Wiley, Chichester

Lawton J H, Brotherton P N M, Brown V K, Elphick C, Fitter A H, Forshaw J Haddow R,W, Hilborne S, Leafe R, N, Mace G M, Southgate M P, Sutherland W J, Tew T E, Varley J and Wynne G R 2010 Making Space for Nature: a review of England's wildlife sites and ecological network. Report to DEFRA

Lindenmayer D B and Fischer J 2006 Habitat Fragmentation and Landscape Change: An Ecological and Conservation Synthesis Island Press, Washington Lindenmayer D B, Hobbs R J, Montague-Drake R, Alexandra J, Bennett A, Burgman M, Cale P, Calhoun A, Cramer V, Cullen P, Driscoll D, Fahrig L, Fischer J, Franklin J, Haila Y, Hunter M, Gibbons P, Lake S, Luck G, MacGregor C, McIntyre S, Mac Nally R, Manning A, Miller J, Mooney H, Noss R, Possingham H, Saunders D, Schmiegelow F, Scott M, Simberloff D, Sisk T, Tabor G, Walker B, Wiens J, Woinarski J, Zavaleta E 2008 A checklist for ecological management of landscapes for conservation Ecology Letters 11 78-91

Lockie S and Higgins V 2007 Roll-out neoliberalism and hybrid practices or regulation in Australian agri-environmental governance Journal of Rural Studies 23 1-11

Logan S and Wekerle G R 2008 Neoliberalizing environmental governance? Land trusts, private conservation and nature on the Oak Ridges Moraine. Geoforum, 39 2097-2108 
Lövbrand E and Stripple J 2006) The climate as political space: on the territorialisation of the global carbon cycle, Review of International Studies 32 217-235.

Lowe P, Marsden T and Whatmore, S eds 1994 Regulating Agriculture David Futon, London.

MacDonald K I 2010 The devil is in the (Bio)diversity: private sector 'engagement' and the restructuring of biodiversity conservation, Antipode 42 513-550

MacDonald K I and Corson C 2012 'TEEB begins now': a virtual moment in the production of natural capital, Development and Change 43 159-184

Macgregor N A, Adams W M Hill C T, Eigenbrod F. and Osborne P E 2012

'Large-scale conservation in Great Britain: taking stock', Ecos 33 (3/4) 13-23

Margules C R and R L Pressey 2000 Systematic conservation planning Nature 405 243-253.

McCarthy J 2005 Devolution in the woods: community forestry as hybrid neoliberalism Environment and Planning A 37 995-1014

McCarthy J and Prudham S 2004 Neoliberal nature and the nature of neoliberalism Geoforum 35 275-283

McCauley D J 2006 Selling out on nature Nature 44327-28

McFarlane R 2007 The Wild Places Granta Books and Penguin Books, London and New York

Moore N W 1962 The heaths of Dorset and their conservation Journal of Ecology 50 369-91

Myers N, Mittermeier R A, Mittermeier C M, da Fonseca, G A B and Kent, J 2000 Biodiversity hotspots for conservation priorities Nature 403 853-858

Natural England 2008 http://www.naturalengland.org.uk/ourwork/conservation/biodiversity/protectand manage/integratedbiodiversitydeliveryareas/default.aspx (accessed 9 August 2012)

Natural England 2009 Economic valuation of upland ecosystem services, Natural England Commissioned Report NECR029, Natural England, Sheffield

Natural England 2010 Lost Life: England's lost and threatened species Natural England NE233

Natural England 2011 Biodiversity 2020: a strategy for England's wildlife and ecosystem services, DEFRA, London 
Natural England 2013 Marlborough Downs NIA, http://www.naturalengland.org.uk/ourwork/conservation/biodiversity/funding/ni a/projects/marlboroughdowns.aspx (accessed 26 April 2013)

Neumann R P 2004 Nature-state-territory: towards a critical theorization of conservation enclosures, Peet, R and Watts M eds, Liberation ecologies: environment, development, social movement Routledge, London, 195-217

Norgaard R B 2010 Ecosystem services: from eye-opening metaphor to complexity blinder Ecological Economics 69 1219-1227

Ostrom E 1990 Governing the Commons Cambridge University Press, Cambridge

Pawliczek J and Sullivan S 2011 Conservation and concealment in SpeciesBanking.com, USA: an analysis of neoliberal performance in the species offsetting industry, Environmental Conservation 38 435-444.

Peck J and Tickell A 2002 Neoliberalizing space Antipode 34 380-404

Peck J, Theodore N and Brenner N 2010 Postneoliberalism and its malcontents Antipode 41 94-116

Peluso N 1993 Coercing conservation: the politics of state resource control. Global Environmental Change 3: 199-217.

Pound D 2009 The eco what approach? Ecos: A Review of Conservation 30(2) 17-27

Ravenel R M, and Redford, K H 2005 Understanding IUCN Protected Area categories, Natural Areas Journal 25: 381-389.

Redford K H and Adams W M 2009 Payment for ecosystem services and the challenge of saving nature Conservation Biology 23 785-7

Robertson M M 2004 The neoliberalization of ecosystem services: wetland mitigation banking and problems in environmental governance Geoforum 35 $361-373$

Robertson M M 2006 The nature that capital can see: science, state, and market in the commodification of ecosystem services Environment and Planning D 24 $367-387$

RSPB 2001 Futurescapes: large-scale habitat restoration for wildlife and people The Royal Society for the Protection of Birds, Sandy, UK

RSPB 2010 Futurescapes: space for nature, land for life. [online] Available at: $<$ http://www.rspb.org.uk/images/futurescapesuk_tcm9-253866.pdf $>$ [Accessed 08.07.11] 
Runte A 1987 National Parks: the American experience, Lincoln: University of Nebraska Press

Sachedina T 2010 Disconnected Nature: The scaling up of African Wildlife Foundation and its impacts on biodiversity conservation and local livelihoods, Antipode 42 603-623

Sandberg A 2007 Property rights and ecosystem properties Land Use Policy 24 613623

Schroeder R A 1999 Geographies of environmental intervention in Africa. Progress in Human Geography 23 359-78.

Scott J C 1998 Seeing Like a State: how certain schemes to improve the human condition have failed Yale University Press, New Haven.

Sheail J 1976 Nature in Trust: the history of nature conservation in Great Britain Blackie, Edinburgh

Sheail J 1988 The great divide: an historical approach Landscape Research 13 2-5

Sheail J 1998 Nature Conservation in Britain: the formative years The Stationery Office, London

Sheail J 2010 Nature's spectacle: the world's first national parks and protected places, Earthscan, London.

Shucksmith M and Ronningen K 2011 The uplands after neoliberalisation? The role of the small farm in rural sustainability Journal of Rural Studies 27 275-87

Sievanen L, Gruby, R L and Campbell, L 2013 Fixing Marine Governance in Fiji? The New Scalar Narrative of Ecosystem-Based Management, Global Environmental Change 23 206-216

Southwood T R E 1977 Habitat: a templet for ecological strategies?' Journal of Animal Ecology 46 337-365

Spierenburg M and Wels H 2010 Conservative philanthropists, royalty and business elites in nature conservation in southern Africa Antipode 42 647-670

Sullivan S 2012 Banking nature? The spectacular financialisation of environmental conservation Antipode 198-217

Swetnam R D, Mountford J O, Manchester S J M and Broughton R 2004 Agrienvironmental schemes: their role in reversing floral decline in the Brue floodplain, Somerset, UK Journal of Environmental Management 71 79-93

Symes W, Bradbury R and Lonergan A 2011 Landscape Scale Conservation - the scientific basis RSPB (unpublished report) 
Taylor P 2005 Beyond Conservation: a wildland strategy Earthscan, London

Terborgh J 1976 'Island biogeography and conservation: strategy and limitations Science 1931029

Thomas C D, Cameron A and Green R E et al. 2004 Extinction risk from climate change Nature 427 195-8

Tunbridge J E (1978) 'Conservation trusts as geographical agents': their impact upon landscape, townscape and land use Transactions of the Institute of British Geographers 6 103-25.

UK NEA 2011 The UK National Ecosystem Assessment: Technical Report UNEPWCMC, Cambridge

Vera F 2009 Large-scale nature development - the Oostvaardesplassen British Wildlife 20 (5) 28-36

Wainwright J and Robertson M (2003) Territorialization, science, and the colonial state: the case of Highway 55 in Minneapolis, USA Cultural Geographies 10 196-217

Ward V, Fisher M and Carver S 2006 Re-wilding projects in the UK - the database Ecos: A Review of Conservation 27(3/4) 5-7.

Wildlife Trusts 2007 A Living Landscape: a call to restore Britain's battered ecosystems, for wildlife and people The Wildlife Trusts, Lincoln

Wildlife Trusts 2011 The Wildlife Trusts: A Living Landscape [online] Available at: $<$ http://www.wildlifetrusts.org/alivinglandscape $>$ [Accessed 07.07.11].

Woodland Trust 2002 Space for Nature: landscape-scale action for woodland biodiversity, The Woodland Trust, Grantham.

Zimmerer K S 2006 Geographical perspectives on globalization and environmental issues: the inner-connections of conservation, agriculture and livelihoods, Globalization and New Geographies of Conservation University of Chicago Press, Chicago 1-43

Zimmerer K S 2000 The Reworking of Conservation Geographies: nonequilibrium landscapes and nature-society hybrid Annals of the Association of American Geographers 90 356-69

\section{Acknowledgments}


1

2

3

4

5

6

7

8

9

10

11

12

13

14

15

16

17

18

19

20

21

22

23

24

25

26

27

28

29

30

31

32

33

34

35

36

37

38

39

40

41

42

43

44

45

46

47

48

49

50

51

52

53

54

55

56

57

58

59

60

This research was funded by the University of Cambridge Moran Fund. We would like to thank the editor and referees for advice on the manuscript. 


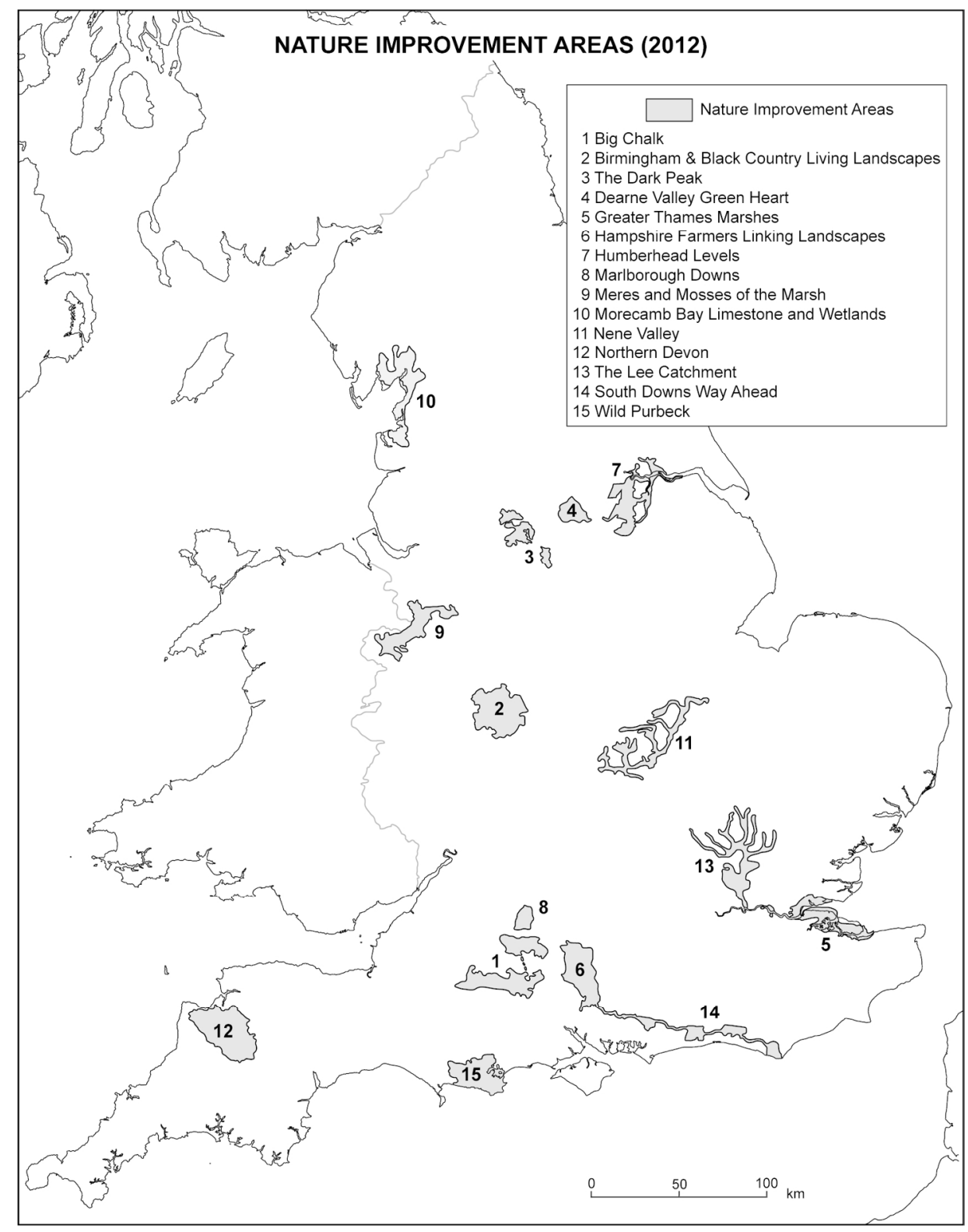

$144 \times 185 \mathrm{~mm}(300 \times 300 \mathrm{DPI})$ 
Size distribution of Large Conservation Areas

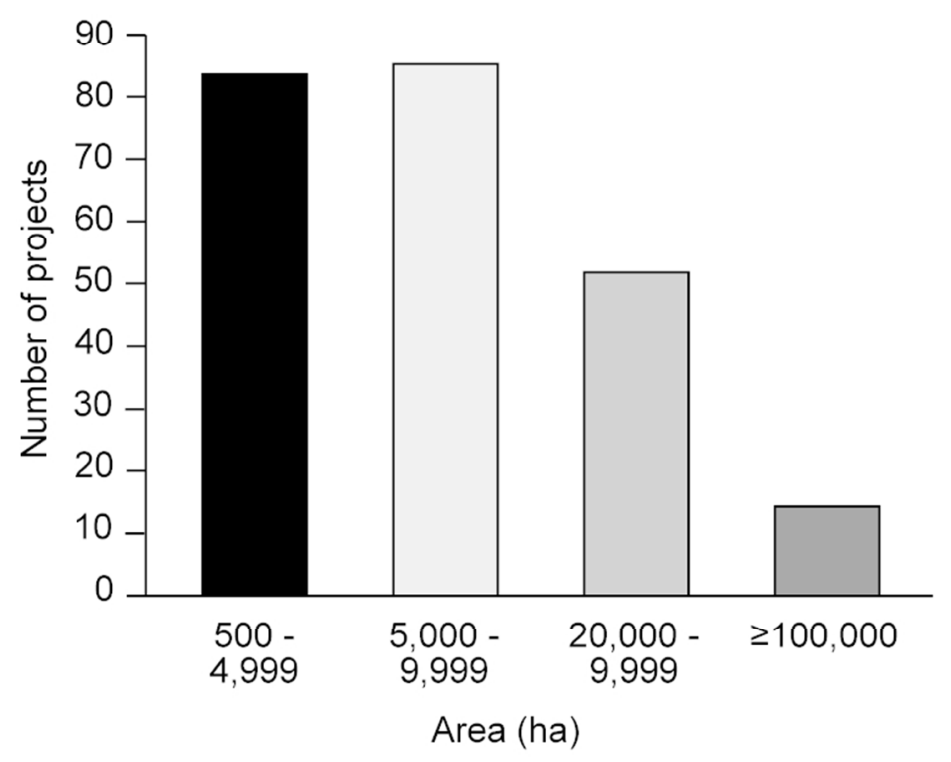

\section{Percent of total area}

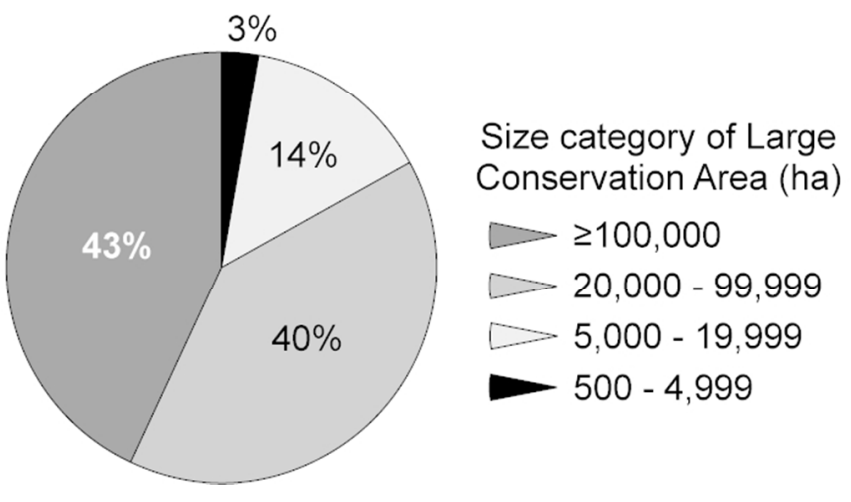

$63 \times 108 \mathrm{~mm}(300 \times 300 \mathrm{DPI})$ 


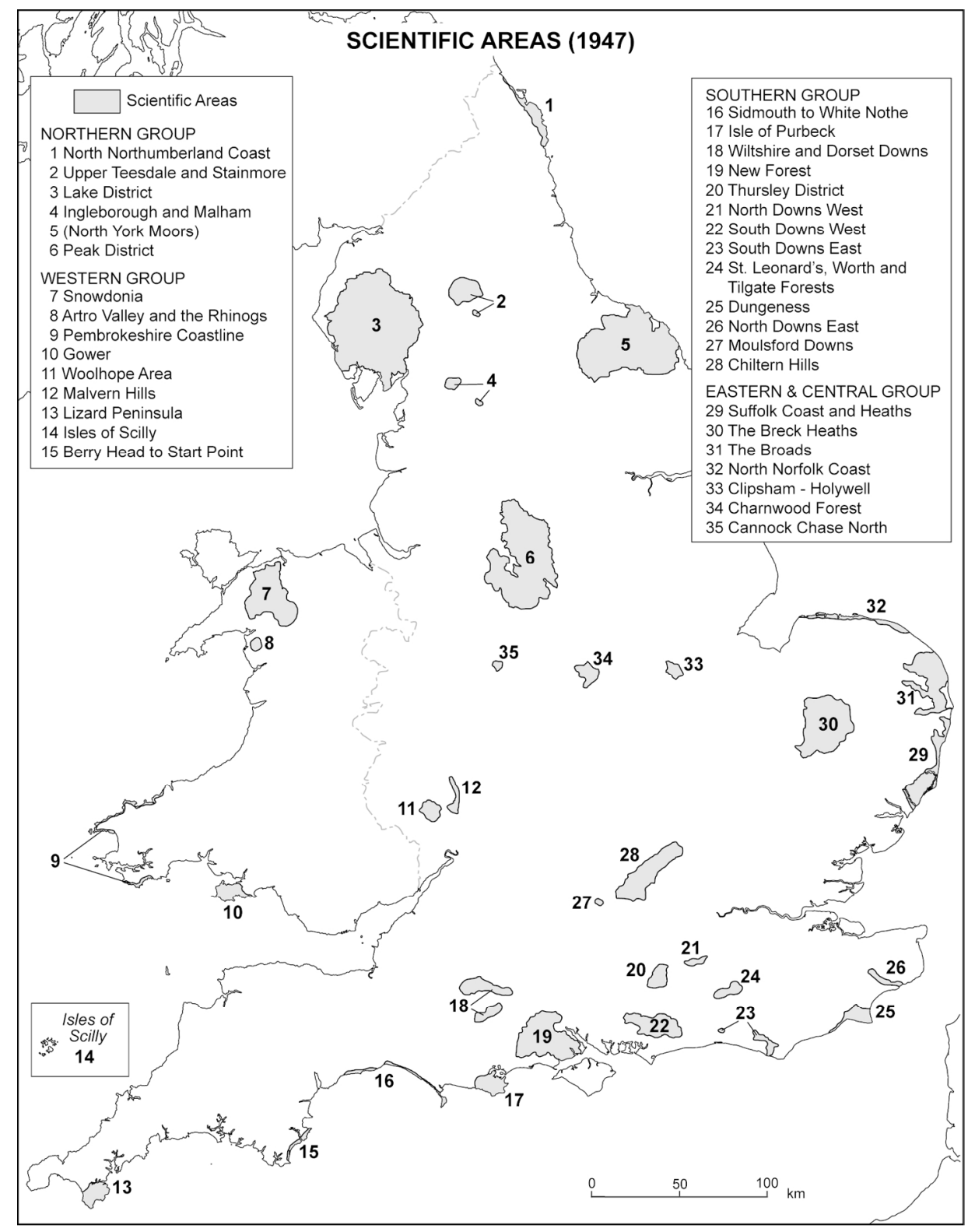

$144 \times 185 \mathrm{~mm}(300 \times 300$ DPI $)$ 
Table 1. Large conservation area project partners

\author{
Category of Examples \\ partner \\ organisation \\ Government \\ Defra, Ministry of Defence, Welsh Assembly Government \\ Departments \\ Non departmental British Waterways, Centre for Ecology and Hydrology, Countryside \\ public bodies Council for Wales, English Heritage Environment Agency, Forestry \\ Commission (and Forest Enterprise), Natural England, Scottish Natural \\ Heritage \\ Utilities Internal Drainage Boards, Network Rail, water companies \\ Non-profit $\quad$ British Trust for Ornithology, British Trust for Conservation Volunteers; \\ organisations / Community organisations and associations; Farming \& Wildlife \\ Charities Advisory Group; John Muir Trust; National Trust; Royal Society for the \\ Protection of Birds; Scottish National Trust; Wildfowl and Wetlands \\ Trust; Woodland Trust; Wildlife Trusts. \\ Local Authorities Borough Councils, Community Councils, District Councils, , National \\ / Local Park and AONB Authorities (including Broads Authority) \\ Government \\ Private \\ development companies, energy companies (e.g. Mercia Energy Ltd.), \\ Businesses; \\ estates, mineral companies (e.g. Cemex, Aggregate companies) \\ Education Schools, colleges, universities (e.g. Scottish Agricultural College, \\ Institutions Imperial College)
}

